\title{
LOW METAL LOADING CATALYSTS USED FOR THE SELECTIVE HYDROGENATION OF STYRENE
}

\author{
Juan Badano*, Cecilia Lederhos, Mónica Quiroga y Pablo L’Argentière \\ Instituto de Investigaciones en Catálisis y Petroquímica, Facultad de Ingeniería Química, Universidad Nacional del Litoral, Consejo \\ Nacional de Investigaciones Científicas y Técnicas, Santiago del Estero 2654, 3000 Santa Fe, Argentina \\ Fernando Coloma-Pascual \\ Servicios Técnicos de Investigación, Facultad de Ciencias, Universidad de Alicante, Apartado 99, E-03080 Alicante, Spain
}

Recebido em 1/12/08; aceito em 17/6/09; publicado na web em 25/11/09

\begin{abstract}
A series of Group VIII metal catalysts was obtained for the semi-hydrogenation of styrene. Catalysts were characterized by Hydrogen Chemisorption, TPR and XPS. Palladium, rhodium and platinum low metal loading prepared catalysts presented high activity and selectivity (ca. 98\%) during the semi-hydrogenation of styrene, being palladium the most active catalyst. The ruthenium catalyst also presented high selectivity (ca. 98\%), but the lowest activity. For the palladium catalyst, the influence of the precursor salt and of the reduction temperature on the activity and selectivity were studied. The following activity series was obtained: PdN-423 > PdCl-673 > PdCl-373> PtCl-673 > RhCl-673 > RuCl-673. As determined by XPS, differences in activity could be attributed, at least in part, to electronic effects.
\end{abstract}

Keywords: selective hydrogenation; metal catalysts; styrene.

\section{INTRODUCTION}

In the last decade, around $35 \%$ of the gasoline consumed in USA came from cracking processes; moreover, ca. 20-40\% of the gasoline consumed in the whole world was supplied by cracking processes. ${ }^{1,2}$ The petroleum cracking process generate fractions rich in benzene, toluene, xylenes (BTX), and gasoline, known as $\mathrm{C}_{5+}$ streams, with high contents in olefins, diolefines and styrene (up to $15 \mathrm{wt} \%$ ). ${ }^{3-5}$ Due to their unstable character, diolefines and styrene should be eliminated to prevent the formation of gums in later processes or during storage. ${ }^{1}$ The catalytic hydrogenation of olefins is the most used industrial process. ${ }^{6,7}$ Styrene is a good model compound of BTX and gasoline fractions because it is one of the slower reacting components that should be removed. ${ }^{1}$ Styrene may be hydrogenated to ethylbenzene, ethylciclohexane and also could polimerize deactivating the active sites of the catalysts. In Figure 1 it can be seen the possible reaction paths.
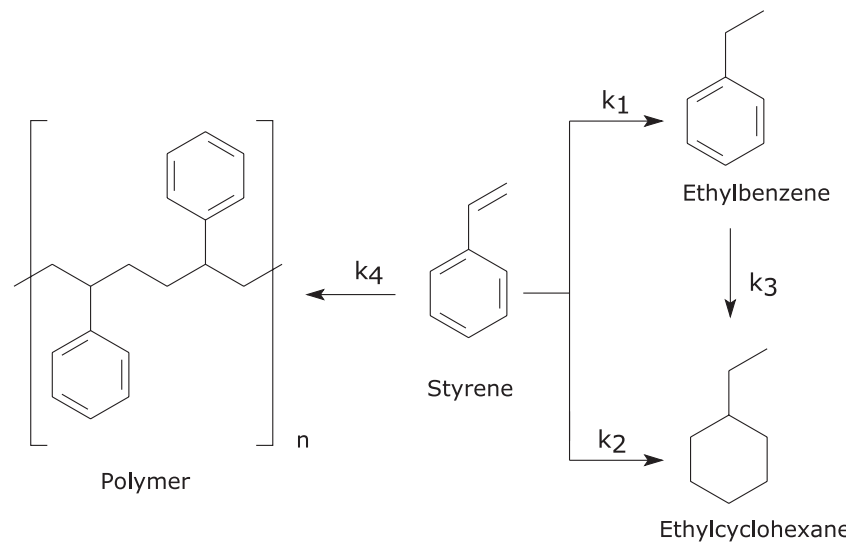

Figure 1. Schematic reaction path for the styrene hydrogenation

The hydrogenation must be selective without modification of the valuable aromatic nucleus. The group VIII metals such as $\mathrm{Rh}, \mathrm{Ru}, \mathrm{Pt}$ and Ir are well known as hydrogenation catalysts. ${ }^{8}$ Among them, the

\footnotetext{
*e-mail: jbadano@fiq.unl.edu.ar
}

platinum group metals catalysts allow carring out hydrogenations at milder conditions than other metals, like $\mathrm{Ni}$, for industrial applications. ${ }^{9}$ Styrene hydrogenation in particular has been studied with palladium and nickel catalysts using relatively mild conditions. ${ }^{10,11}$

The continuous increase of the petroleum raw's price and the variable price of Group VIII metals used as catalysts in the hydrogenation reactions, make interesting to investigate the influence of these metals on the activity and selectivity during the selective hydrogenation of exo-cyclic double bonds C-C.

The objective of the present work is to investigate the influence of the reduction temperature and of the precursor salt on the activity of several supported Group VIII catalysts with low metal loading, during the styrene semi-hydrogenation carried out in liquid phase.

\section{EXPERIMENTAL}

The catalysts were prepared by incipient wetness using $\gamma-\mathrm{Al}_{2} \mathrm{O}_{3}$ as support (CK-300, mesh 35-80, calcined $4 \mathrm{~h}$ at $823 \mathrm{~K}, 180 \mathrm{~m}^{2} \mathrm{~g}^{-1}$ BET surface area). To study the influence of the metals and of the precursor salts, different acidic solutions $(\mathrm{pH}=1)$ were prepared. The precursors employed were: $\mathrm{PdCl}_{2}$ and $\mathrm{Pd}\left(\mathrm{NO}_{3}\right)_{2} \cdot 2 \mathrm{H}_{2} \mathrm{O}$ (Fluka, Cat $\mathrm{N}^{\mathrm{o}}$ : 76050 and 76070 , respectively, purity $\left.>99.98 \%\right), \mathrm{RuCl}_{3} \cdot \mathrm{H}_{2} \mathrm{O}$, $\mathrm{RhCl}_{3} \cdot \mathrm{xH}_{2} \mathrm{O}$ and $\mathrm{H}_{2} \mathrm{PtCl}_{6} \cdot \mathrm{H}_{2} \mathrm{O}$ (Strem Chemicals, Cat $\mathrm{N}^{\mathrm{o}}$ : 44-5880, 45-1880 and 78-0200, respectively, purity $>99.9 \%$ ). Different acidic solutions of the choride precursor salt were prepared using $\mathrm{HCl}$ at $\mathrm{pH}=1$. For $\mathrm{Pd}\left(\mathrm{NO}_{3}\right)_{2} \cdot 2 \mathrm{H}_{2} \mathrm{O}$ an acidic solution was prepared using $\mathrm{HNO}_{3}$ at $\mathrm{pH}=1$. The concentration of the solutions were calculated in order to obtain a metal loading, $\mathrm{M} / \gamma-\mathrm{Al}_{2} \mathrm{O}_{3}(\mathrm{M}=\mathrm{Pd}, \mathrm{Ru}, \mathrm{Pt}, \mathrm{Rh})$, of $0.35 \mathrm{wt} \%$. The $\gamma-\mathrm{Al}_{2} \mathrm{O}_{3}$ was impregnated with each solution following the incipient wetness technique. ${ }^{12}$ The impregnated solids were dried during $24 \mathrm{~h}$ at $393 \mathrm{~K}$, and then they were calcined under an air flow during $4 \mathrm{~h}$ at different temperatures: Pd at $673 \mathrm{~K}$ and Pt, $\mathrm{Ru}$ and $\mathrm{Rh}$ at $773 \mathrm{~K}$. Prior to reaction, the catalysts were reduced with $\mathrm{H}_{2}$ during $1 \mathrm{~h}$ at different temperatures: $\mathrm{Pt}, \mathrm{Ru}$ and $\mathrm{Rh}$ at 673 $\mathrm{K}$, Pd prepared from $\mathrm{PdCl}_{2}$ at 373 and $673 \mathrm{~K}$, and $\mathrm{Pd}$ prepared from $\mathrm{Pd}\left(\mathrm{NO}_{3}\right)_{2}$ at $423 \mathrm{~K}$. For the most active catalyst, the influence of the precursor salt and of the reduction temperature were studied. The metal loading of the catalysts was obtained by spectrophotometric determinations. 
The dispersion and the Temperature Programmed Reduction (TPR) determinations for each metal catalyst were determined using a Micromeritics Auto Chem II equipment equipped with a thermal conductivity detector and cold water trap before the entering the thermal detector .

Dispersion values were obtained after reducing each sample at the above mentioned temperatures. The samples were degassed in situ for $2 \mathrm{~h}$ under an argon flow (AGA purity 99.99\%), and then cooled at room temperature except palladium catalysts, which were cooled at $373 \mathrm{~K}$ where the formation of palladium hydride is negligible. ${ }^{13}$ After that, the chemisorption with hydrogen was performed.

During the TPR analysis, the samples were dried in situ at $423 \mathrm{~K}$ for $1 \mathrm{~h}$ under an argon flow (AGA purity 99.99\%). After that, the samples were cooled up to $250 \mathrm{~K}$ in the same atmosphere. Then the temperature was incresed up to $1073 \mathrm{~K}$ at $10 \mathrm{~K} \mathrm{~min}^{-1}$ in a gas flow containig $5 \%$ $(\mathrm{v} / \mathrm{v})$ hydrogen/argon, at a total flow rate of $40 \mathrm{~mL} \mathrm{~min}^{-1}$.

The superficial electronic state of each metal and of chlorine and their atomic ratios were studied by X-ray Photoelectron Spectroscopy (XPS) following the Pd $3 \mathrm{~d}_{5 / 2}, \mathrm{Pt} 4 \mathrm{~d}_{5 / 2}, \mathrm{Rh} 3 \mathrm{~d}_{5 / 2}, \mathrm{Ru} 3 \mathrm{~d}_{5 / 2}$. and $\mathrm{Cl} 2 \mathrm{p}_{3 / 2}$ peaks position, respectively. As a consequence of the interference of the $\mathrm{Al} 2 \mathrm{p}$ line, the $\mathrm{Pt} 4 \mathrm{~d}_{5 / 2}$ peak position was followed instead of the most common $\mathrm{Pt} 4 \mathrm{f}_{7 / 2}$. To correct possible deviations caused by electronic charge on the samples the $\mathrm{Al} 2 \mathrm{p}$ line was taken as an internal standard at $74.4 \mathrm{eV}$ but also taking into account the low intense $\mathrm{C} 1 \mathrm{~s}$ peak at $284.6 \mathrm{eV}$. Measurements were made using a VG-Microtech Multilab equipment, a $\mathrm{MgK}_{\alpha}(\mathrm{hv}: 1253.6 \mathrm{eV}$ ) radiation and a pass energy of $50 \mathrm{eV}$. The XPS system analysis pressure was kept at $5 \times 10^{-7} \mathrm{~Pa}$. Samples were treated in situ with $\mathrm{H}_{2}$ following the same procedure as that for catalyst preparation. A careful deconvolution of the spectra was made. The areas under the peaks were estimated by calculating the integral of each peak after subtracting a Shirley background and fitting the experimental peak to a combination of Lorentzian/Gaussian lines of $30-70 \%$ proportions. ${ }^{14}$

The styrene selective hydrogenation was carried out in a batch PTFE coated stainless steel stirred tank reactor fed with $200 \mathrm{~mL}$ of a solution of $10 \%(\mathrm{v} / \mathrm{v})$ styrene (Aldrich, Cat. $\mathrm{N}^{\circ} \mathrm{S} 497-2$, purity $>99 \%$ ) in toluene (Merck, Cat. $\mathrm{N}^{\circ}$ TX0735-44, purity $>99 \%$ ), using n-decane (Fluka, Cat. $\mathrm{N}^{\circ} 30550$, purity $>98 \%$ ) as an internal standard. The reactor was operated at $353 \mathrm{~K}, 10$ bar $\mathrm{H}_{2}$ and $800 \mathrm{rpm}$. Runs were carried out in triplicate with an experimental error of $3 \%$, using $0.2 \mathrm{~g}$ of catalyst and a styrene/M molar ratio equal to $2.610^{4}$. Internal and external diffusional limitations were absent in the conditions of this work. Reactant and products were analyzed by GC equipped with a FID detector.

\section{RESULTS AND DISCUSSION}

Figure 2 shows the TPR profiles for the Pd (a), platinum and rhodium (b) and ruthenium (c) catalysts. As shown in Figure 2a, for both Pd precursor salts, a characteristic peak at $292 \mathrm{~K}$ was observed, corresponding to the reduction of $\mathrm{PdO}$ species weakly interacting with the support. ${ }^{15} \mathrm{~A}$ desorption peak at approximately $339 \mathrm{~K}$ was attributed to the decomposition of $\beta-\mathrm{PdH}_{\mathrm{x}}$ species. ${ }^{15,16}$ The catalyst prepared from $\mathrm{PdCl}_{2}$ also presented a peak at $448 \mathrm{~K}$, which could be attributed to the partial reduction of Pd-chlorine-containing species, such as $\mathrm{Pd}_{\mathrm{x}} \mathrm{Cl}_{\mathrm{y}} \mathrm{O}_{\mathrm{z}} \cdot{ }^{17}$ As shown in the curves depicted in Figures $2 \mathrm{~b}$ and $2 \mathrm{c}, \mathrm{TPR}$ results indicated that at $670 \mathrm{~K} \mathrm{Pt}, \mathrm{Rh}$ and $\mathrm{Ru}$ catalysts were reduced.

Table 1 presents the metal loading (w), metal dispersion (D), the XPS results for the metals and for chlorine and the activity results, expressed as Turn Over Frequencies (TOF) for the different catalysts. In Figure 3 are shown the XPS profiles of: palladium (a), platinum (b), rhodium (c) and ruthenium (d) catalysts. For the dispersion calculations a $\mathrm{H} / \mathrm{M}=1$ ratio was adopted. ${ }^{18-21} \mathrm{PdCl}-673, \mathrm{PdCl}-373$ and $\mathrm{PtCl}-673$ presented the higher dispersion values, probably due to the formation of $\mathrm{Pd}_{\mathrm{x}} \mathrm{Cl}_{\mathrm{y}} \mathrm{O}_{\mathrm{z}}{ }^{17}$ and $\mathrm{Pt}_{\mathrm{x}} \mathrm{Cl}_{\mathrm{y}} \mathrm{O}_{\mathrm{z}}{ }^{22}$ species. On the palladium and platinum
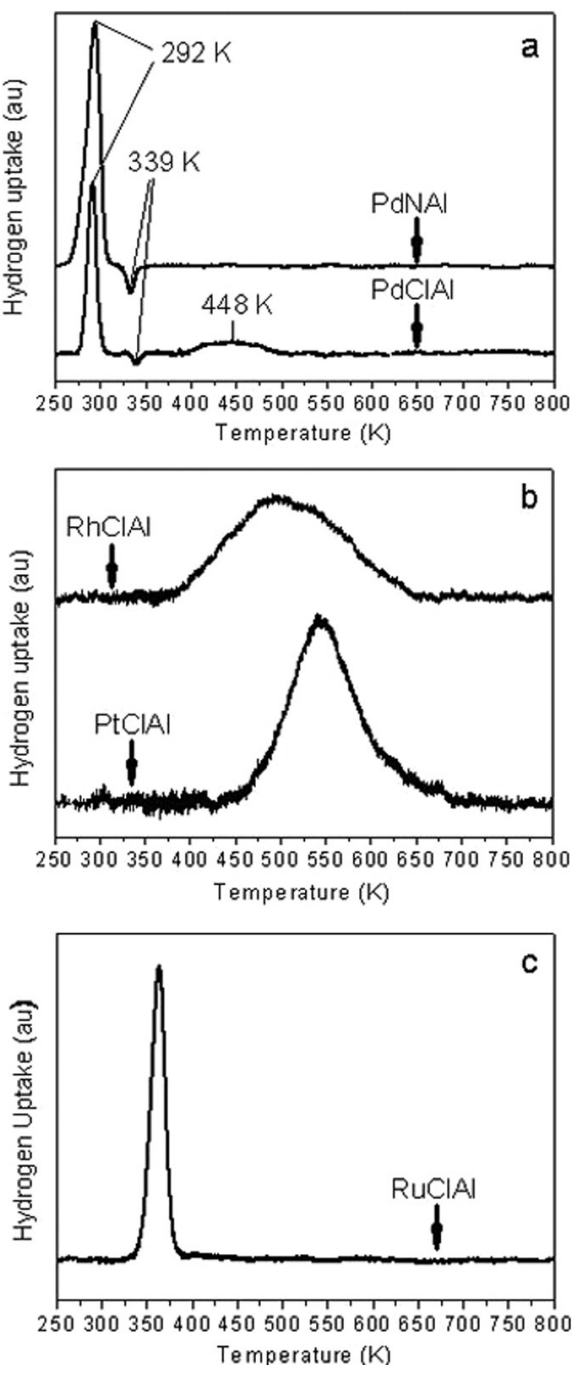

Figure 2. TPR profiles of: palladium (a), platinum and rhodium (b) and ruthenium (c) catalysts

catalysts prepared from chlorine precursors (PdCl-673, PdCl-373 and $\mathrm{PtCl}-673$ ) the XPS results showed the presence of the $\mathrm{Cl} 2 \mathrm{p}_{3 / 2}$ peak at ca. $198.5 \mathrm{eV}$, corresponding to superficial chloride species, ${ }^{23}$ indicating that chlorine was not completely eliminated after reduction. As shown in Figure 3, the $\mathrm{Pd} 3 \mathrm{~d}_{5 / 2}$ peak position for PdN-423, $334.7 \mathrm{eV}$, could be assigned to $\mathrm{Pd}^{0}{ }^{23}$ The $\mathrm{Pd} 3 \mathrm{~d}_{5 / 2}$ peak position for catalysts $\mathrm{PdCl}-673$ and $\mathrm{PdCl}-373,335.4$ and $335.9 \mathrm{eV}$, respectively, could be assigned to electron-deficient species, $\mathrm{Pd}^{n+}$, with $n$ between 0 and $2 .{ }^{23}$ It can also be seen for the last two catalysts that the hydrogen treatment temperature influenced the amount of superficial chlorine, as the $\mathrm{Cl} / \mathrm{Pd}$ atomic ratio for PdCl-373 was almost seven times higher than that for PdCl-673. For the PtCl-673 catalyst, in Figure 3b, two peaks were observed: one at $313.8 \mathrm{eV}$, assigned to $\mathrm{Pt}^{0}$, and another one at $315.8 \mathrm{eV}$, that could be assigned to electron-deficient species, $\mathrm{Pt}^{n+}$, with $n$ between 0 and $2 .{ }^{23}$ The atomic proportions of each Pt species are also shown in Table 1. The XPS results obtained for $\mathrm{Ru} 3 \mathrm{~d}_{5 / 2}$ and $\mathrm{Rh} 3 \mathrm{~d}_{5 / 2}$ indicated the presence of superficial $\mathrm{Ru}^{0}$ and $\mathrm{Rh}^{0}$ species. ${ }^{23}$

The selectivity for all the catalysts was ca. $98 \%$. Figure 4 shows the styrene total conversion as a function of time. It can be seen that initially the reaction order was 0 in styrene, and that it changed to 1 at high conversions. Then, a Langmuir-Hinshelwood-type kinetic model can be suggested. ${ }^{1}$ As shown in Figure 4, the Pd catalyst presented the highest conversion vs. time values; hence, it appe- 
Table 1. Reduction temperature $\left(\mathrm{T}_{\mathrm{R}}\right)$, metal loading $(\mathrm{w})$, metal dispersion $(\mathrm{D})$, metals and chlorine binding energies and $\mathrm{Cl} / \mathrm{M}$ atomic superficial ratio determined by XPS and TOF for the different catalysts evaluated

\begin{tabular}{llllllll}
\hline Catalyst & $\begin{array}{l}\mathrm{T}_{\mathrm{R}} \\
(\mathrm{K})\end{array}$ & $\begin{array}{l}\mathrm{w} \\
(\%)\end{array}$ & $\begin{array}{l}\mathrm{D} \\
(\%)\end{array}$ & $\begin{array}{l}\mathrm{M} \\
(\mathrm{eV})\end{array}$ & $\begin{array}{l}\mathrm{Cl} 2 \mathrm{p}_{3 / 2} \\
(\mathrm{eV})\end{array}$ & $\begin{array}{l}\mathrm{Cl} / \mathrm{M} \\
(\mathrm{at} / \mathrm{at} .)\end{array}$ & $\begin{array}{l}\mathrm{TOF} \\
\left(\mathrm{s}^{-1}\right)\end{array}$ \\
\hline PdN-423 & 423 & 0.31 & 26 & 334.7 & - & 0 & 61.9 \\
PdCl-673 & 673 & 0.34 & 38 & 335.4 & 198.6 & 1.6 & 45.0 \\
PdCl-373 & 373 & 0.34 & 37 & 335.9 & 198.5 & 10.9 & 2.4 \\
PtCl-673 & 673 & 0.33 & 39 & $313.8^{\mathrm{a}}$ & 198.5 & 31.0 & 27.9 \\
RhCl-673 & 673 & 0.32 & 20 & 306.9 & - & 0 & 0 \\
RuCl-673 & 673 & 0.30 & 3 & 279.5 & - & & 0 \\
\hline
\end{tabular}

M: $\mathrm{Pd} 3 \mathrm{~d}_{5 / 2}, \mathrm{Pt} 4 \mathrm{~d}_{5 / 2}, \operatorname{Rh~} 3 \mathrm{~d}_{5 / 2}$ or $\mathrm{Ru} 3 \mathrm{~d}_{5 / 2} .{ }^{\text {a }} 28 \%$ atomic. ${ }^{\text {b }} 72 \%$ atomic.
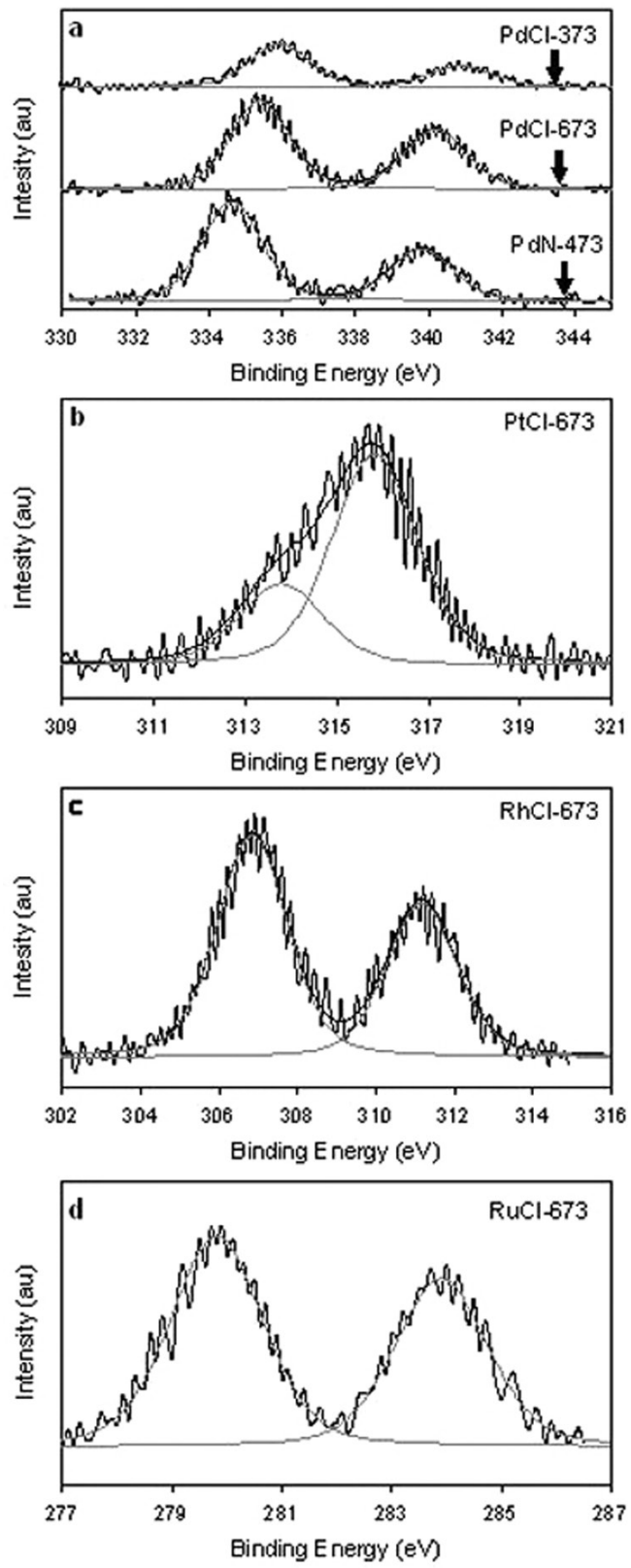

Figure 3. XPS profiles of: palladium (a), platinum (b), rhodium (c) and ruthenium (d) catalysts ared interesting to study the influence of chlorine in its catalytic performance. For this reason, and only in the case of Pd, we used also a nitrate precursor.

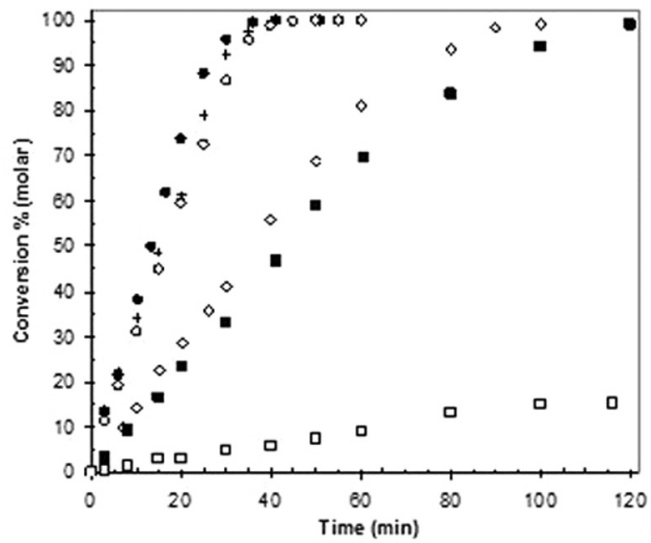

Figure 4. Styrene total conversion as a function of time for the different ca-

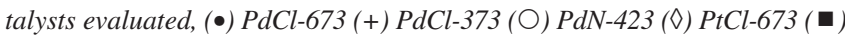
$\mathrm{RhCl}-673$ ( $\square) \mathrm{RuCl}-673$

TOF values were calculated from the conversion initial values. These results indicated the following order of activities: $\mathrm{Pd}\left(\mathrm{NO}_{3}\right)_{2}>\mathrm{PdCl}_{2}>\mathrm{PtCl}_{6} \mathrm{H}_{2}>\mathrm{RhCl}_{3}>>\mathrm{RuCl}_{3}$. The bibliography lacks of papers comparing the activity and selectivity among metals of the VIII group used as monometallic catalysts in the same operational conditions during the selective hydrogenation of high molecular mass olefinic compounds, such as styrene. For other particular reaction systems, several relative activity series can be found in the literature; as reported in the review of Hagen, these series can widely differ. ${ }^{24}$ The differences in activity between the catalysts prepared from the chloride salts could be attributed, at least in part, to differences in the electronic density of the external $d$ orbitals of each metal: $\mathrm{Pd}, \mathrm{d}^{10} ; \mathrm{Pt}, \mathrm{d}^{9}$; $\mathrm{Rh}, \mathrm{d}^{8}$ and $\mathrm{Ru}, \mathrm{d}^{7}$. For both palladium precursors, $\mathrm{Pd}\left(\mathrm{NO}_{3}\right)_{2}$ and $\mathrm{PdCl}_{2}$, reduced at different temperatures, the following order of activities was observed: PdN-423 > PdCl-673 > PdCl-373. The differences in activity for the Pd catalysts could be attributed to the presence of $\mathrm{Pd}^{0}$ or electron-deficient species, $\mathrm{Pd}^{n+}$, on each catalyst. The higher activity (TOF value) was obtained for $\mathrm{Pd}^{0}$. It is broadly accepted in the bibliography that the electron-deficient $\mathrm{Pd}^{n+}$ species are less active as they have less d electrons available for interacting with the substrate. ${ }^{25}$ 


\section{CONCLUSIONS}

Palladium, rhodium and platinum low metal loading prepared catalysts presented high activity and selectivity (ca. 98\%) during the semi-hydrogenation of styrene. The ruthenium catalyst also presented high selectivity (ca. 98\%), but the lowest activity. The following activity series was obtained: PdN-423 > PdCl-673 > PdCl-373> PtCl-673 > RhCl-673 >> RuCl-673. Differences in activity could be attributed, at least in part, to electronic effects.

\section{ACKNOWLEDGEMENTS}

The experimental assistance of C. Mázzaro and the financial assistance of CONICET, ANPCyT and UNL are greatly acknowledged.

\section{REFERENCES}

1. Nijhuis, T. A.; Dautzenberg, F. M.; Moulijn, J. A.: Chem. Eng. Sci. 2003 , $58,1113$.

2. Choi, J. S.; Maugé, F.; Pichon, C.; Fourcade, J. O.; Jumas, J. C.; Clair, C. P.; Uzio, D.; Appl. Catal., A 2004, 267, 203.

3. Hatch, L. F.; Matar, S.; From Hydrocarbon to Petrochemicals, Gulf Publishing Company: Houston, 1981, chap. 3 and 7.

4. Chauvel, G.; Lefebvre, G.; Petrochemical Processes, Institut Francais du Pétrole Publictions : Paris, 1989, chap. 2.

5. Sadeghbeigi, R.; Fluid Catalytic Cracking Handbook, Gulf Publishing Company: Houston, 2000, chap. 1 and 10.

6. Cheng, Y. M.; Chang, J. R; Wu, J. C; Appl. Catal., A 1986, 24, 273.

7. Derrien, M.L. In Catalytic Hydrogenation, Červený, L., Ed.; Elsevier Publishers: Amsterdam, 1986, vol. 27, p. 652.

8. Bernas, A.; Kumar, N.; Maki-Arvela, P.; Kul'kova, N. V.; Holmbom, B.; Salmi, T.; Yu, D.; Murzin, D.Y.; Appl. Catal., A 2003, 245, 257.
9. Ray, J. D.; J. Am. Oil Chem. Soc. 1985, 62, 1213

10. Hoffer, B. W.; Bonné, R. L. C.; van Langeveld, A. D.; Griffiths, C.; Lok, C. M.; Moulijn, J. A.; Fuel 2004, 83, 1.

11. Damyanova, S.; Daza, L.; Fierro, J. L. G.; J. Catal. 1996, 159, 150.

12. Seoane, X. L.; L'Argentière, P. C.; Fígoli, N. S.; Arcoya, A.; Catal. Lett. 1992, 16, 137

13. Boudart, M.; Hwang, H. S.; J. Catal. 1975, 39, 44

14. Lederhos, C. R.; L’Argentière, P. C.; Coloma-Pascual, F.; Fígoli, N. S.; Catal. Lett. 2006, 110, 23.

15. Gaspar, A. B.; Rosa dos Santos, G.; de Souza Costa, R.; Pereira da Silva, M. A.; Catal. Today 2008, 133, 400.

16. Shen, W.-J.; Okumura, M.; Matsumura, Y.; Haruta, M.; Appl. Catal., A 2001, 213, 225.

17. Gaspar, A. B.; Dieguez, L. C.; Appl. Catal., A 2001, 201, 241.

18. Reyes, P.; Pecchi, G.; Morales, M.; Fierro, J. L. G.; Appl. Catal., A 1997, $163,145$.

19. Mazzieri, V.; Coloma-Pascual, F.; Arcoya, A.; L'Argentière, P. C.; Fígoli, N. S.; Appl. Surf. Sci. 2003, 210, 222

20. Sermon, P. A.; J. Catal. 1972, 24, 460.

21. Li, J.-M.; Huang, F.-Y.; Weng, W.-Z.; Pei, X.-Q.; Luo, C.-R.; Lin, H.-Q.; Huang, C.-J.; Wan H.-L.; Catal. Today 2008, 131, 179.

22. Lieske, H.; Lietz, G.; Spindler, H.; Völter, J.; J. Catal. 1983, 8, 81.

23. NIST X-ray Photoelectron Spectroscopy Database NIST Standard Reference Database 20, Version 3.5 (Web Version), National Institute of Standards and Technology, USA, 2007.

24. Hagen, J.; Industrial Catalysis, A Practical Approach, Wiley-VCH Verlag GmbH \& Co. KgaA: Weinheim, $2^{\text {nd }}$ ed., 2006, p. 150.

25. Karhu, H.; Kalantar, A.; Väyrynen, I. J.; Salmi, T.; Murzin, D. Yu.; Appl. Catal., A 2003, 247, 283. 